\begin{tabular}{|c|c|c|c|c|}
\hline $\begin{array}{c}\text { Prosiding Penelitian \& } \\
\begin{array}{c}\text { Pengabdian Kepada } \\
\text { Masyarakat }\end{array}\end{array}$ & $\begin{array}{c}\text { e ISSN : 2581-1126 } \\
\text { p ISSN : 2442-448X }\end{array}$ & Vol 7, No: 1 & Hal: $173-178$ & April 2020 \\
\hline
\end{tabular}

\title{
PENGEMBANGAN KAPASITAS KELOMPOK KOPERASI CIPACING MANDIRI MELALUI PEMASARAN ONLINE DALAM MENGHADAPI PERDAGANGAN GLOBAL
}

\author{
${ }^{1}$ Risna Resnawaty, ${ }^{2}$ Hetty Krisnani, ${ }^{3}$ Nandang Mulyana \\ 1,2,3Departemen Kesejahteraan Sosial, Fakultas IImu Sosial dan IImu Politik, \\ Universitas Padjadjaran \\ risna.resnawaty@unpad.ac.id1, hettykrisnani@yahoo.com², Mulyanandang@yahoo.com³
}

\begin{abstract}
ABSTRAK
Desa Cipacing merupakan salah satu desa di Kecamatan Jatinangor Kabupaten Sumedang. Desa ini dikenal sebagai desa para pengrajin yang memiliki keterampilan dalam mengolah bahan baku kayu menjadi kerajinan yang telah dipasarkan di tingkat lokal, nasional bahkan internasional. Dengan berlangsungnya Asean-China Free Trade Area, beberapa pengrajin desa Cipacing mengalami kesulitan untuk terus bertahan sebagai pengrajin sebab daya saing yang cukup kuat datang dari kerajinan yang membanjiri pasar lokal yang berasal dari negeri Cina. Dalam konteks pengembangan masyarakat, terdapat salah satu pendekatan yang menekankan pada kekuatan yang dimiliki oleh sebuah komunitas. Komunitas pengrajin Desa Cipacing memiliki karakteristik yang unik, yaitu adanya kemitraan local antara Bandar pengrajin. Penguatan dan pengembangan institusi lokal yang ada di Desa Cipacing dapat diarahkan untuk didirikannya social enterprise berbasis komunitas yang akan memberikan dukungan pada aktifitas ekonomi maupun penyelesaian masalah social yang dihadapi masyarakat. Dengan demikian, langkah yang dapat ditempuh adalah memberikan pelatihan dan pendampingan pada lembaga local di masyarakat agar kapasitas pengrajin Desa Cipacing mampu bersaing dalam pasar global.
\end{abstract}

Kata Kunci: Usaha Kecil Menengah, ACFTA, Insitusi Lokal, Pemasaran Online

\section{ABSTRACT}

Cipacing village is one of the villages in Jatinangor Sumedang district. This village came to be known as of the village a craftsman who having skill in cultivate the raw material of wood Being a craft that has been marketed in the local level, national even international level. With the Asean-China Free Trade Area, Some village craftsman cipacing having trouble to continue to survive as a craftsman because the competitiveness of a strong second set challenge coming from a craft that overwhelm the local market derived from china domestic. In the context of community development, there is one of the approaches emphasis on the power possessed by a community. Community village craftsman cipacing having characteristics unique, namely the existence of local partnership between the banker craftsman. Strengthened and local institutional development in village cipacing could focus to establishment of social enterprise based community to support economic activity that will provide support to the completion of economic activity and social problems faced by the community. Thus, a step that could be pursued is giving training and assistance to local in the community institutions that capacity craftsman village Cipacing to compete in the global market.

Keywords: Small-Medium Enterprise, ACFTA, Local Institution, Online Marketing

\section{PENDAHULUAN}

Pasar bebas ASEAN-Tiongkok yang telah efektif diberlakukan pada tahun 2015 merupakan titik rawan perjuangan UMKM dan ekonomi kerakyatan di Indonesia. Kesepakatan pembentukan jalur perdagangan bebas tersebut dianggap sebagai peluang dan tantangan bagi perekonomian Indonesia. Sebagian kalangan mengkhawatirkan bahwa persaingan impor yang semakin meningkat ini dapat mengganggu sektor industri, namun ada juga yang mengakui bahwa ACFTA akan membuka peluang ekspor baru bagi sektor pertanian. Ada juga yang sangat mengkhawatirkan kesepakatan ini akan mengakibatkan hilangnya pekerjaan di sektor industri padat karya, dan kerugian ini tidak diimbangi dengan penciptaan lapangan kerja baru di sektor ekspor. 


\begin{tabular}{|c|c|c|c|c|}
\hline $\begin{array}{c}\text { Prosiding Penelitian \& } \\
\begin{array}{c}\text { Pengabdian Kepada } \\
\text { Masyarakat }\end{array}\end{array}$ & $\begin{array}{c}\text { e ISSN : 2581-1126 } \\
\text { p ISSN : 2442-448X }\end{array}$ & Vol 7, No: 1 & Hal: $173-178$ & April 2020 \\
\hline
\end{tabular}

Salah satu kelompok UMKM yang mengalami permasalahan dalam menghadapi pasar bebas ACFTA yang masih bertahan dari persaingan ekonomi tersebut adalah Kelompok Koperasi Cipacing Mandir yang dijalankan oleh masyarakat di Desa Cipacing, Kecamatan Jatinangor, Kabupaten Sumedang. kelompok Koperasi Cipacing Mandiri mewadahi 200 orang pengrajin dan 150 orang pedagang. Kelompok Koperasi Cipacing Mandiri menghasilkan produk kerajinan seperti kerajinan senapan angin dan kerajinan alat musik kesenian seperti alat musik jimbe, gendang.

Berdasarkan hasil assesstment awal di Desa Cipacing, tercatat sebanyak 1.415 orang penduduk memiliki mata pencaharian sebagai pengrajin dan 853 orang sebagai pedagang. Jika dilihat dari data lembaga perekonomian yang ada di Desa Cipacing, dapat diketahui bahwa terdapat 80 usaha kerajinan dengan jumlah tenaga kerja mencapai 1.345 orang. Potensi ekonomi di Desa Cipacing dilihat dari kreatifitas masyarakatnya dalam mengolah berbagai kerajinan tangan. Kemampuan mengolah berbagai kerajinan ini merupakan keahlian turun temurun. Setidaknya di Desa Cipacing terdapat 16 jenis kerajinan yang dikembangkan seperti makanan, lukisan, patung, mebel dan alat musik.

Secara organisasi, kelompok Koperasi Cipacing Mandiri masih belum bisa menjalankan usahanya dengan stabil. Permasalahan tersebut didasari dari sumberdaya manusia yang secara keterampilan dan pengetahuan masih terbatas. Hal tersebut dapat dilihat dari managemen koperasi yang masih dilakukan tidak konsisten seperti jadwal kegiatan yang tidak menentu, strategi dan target pemasaran yang belum ada. Keadaan tersebut menghambar perkembangan kelompok Koperasi Cipacing Mandiri untuk menghadapi pasar global ACFTA.

Terkait kebijakan berlakunya ACFTA, kelompok Koperasi Cipacing Mandiri di Desa Cipacing terdampak kepada perputaran ekonomi tidak berkembang dan semakin menurun. Hasil temuan dilapangan diketahui penyebab sulitnya pelaku Kelompok Koperasi Cipacing Mandiri karena akses terkait dengan perijinan eksport barang dan pemanfaatan teknologi yang masih kurang. Kurangnya informasi tersebut menghambat perkembangan usaha kelompok Koperasi Cipacing Mandiri padahal permintaan akan barang dari Malaysia, Filipina, Brunei cukup tinggi namun tidak dapat terpenuhi karena keterbatasan informasi dan pengetahuan Kelompok Koperasi Cipacing Mandiri.

Pemasaran yang dilakukan Kelompok Koperasi Cipacing Mandiri masih dijalankan dengan cara tradisional. Padahal dalam menghadapi pasar global dibutuhkan strategi lain yang efisien yang memudahkan transaksi jual beli. Pasar bebas identik dengan pertukaran jual beli barang yang cepat, mudah dan terpercaya. Perubahan pola pikir dari konsumen sejalan dengan berkembangnya teknologi masa menjadi potensi sendiri untuk dikembangkan. Namun kelompok Koperasi Cipacing Mandiri di desa Cipacing masih kurang memanfaatkan hal tersebut.

Dalam pemasaran dengan teknologi, aspek lainnya yang penting diperhatikan adalah jaminan transaksi dilakukan yang nantinya menimbulkan kepercayaan antara konsumen dan produsen. Sedang dengan media telepon seluler, Facebook dan BBM kerentanan terjadinya penipuan cukup tinggi. Oleh karena itu dibutuhkan strategi pemasaran dengan memanfaat teknologi secara tepat untuk meningkatkan daya saing dan sumber daya manusia khususnya untuk menghadapi pasar bebas ACFTA.

Salah satu strategi dalam mengembangkan kelompok Koperasi Cipacing Mandiri di Desa Cipacing dengan meningkatkan kapasitas Sumber daya manusia dalam memanfaatkan teknologi sebagai media pemasaran dalam bentuk portal web. Dengan memiliki sistem website dan autoresponder yang mampu merespon dan follow up terhadap konsumen, maka sistem akan tetap bekerja 24 jam sehari 7 hari seminggu tanpa menghiraukan kapan dan dimana pengelola berada pada pangsa pasar yang luas. Dengan menggunakan media Internet yang dapat diakses dari belahan dunia mana saja maka internet sangat memungkinkan untuk menjangkau target market yang sangat luas. Jadi apapun produk atau jasa yang dionlinekan akan dapat di promosikan secara elektronik melalui internet. Pemasaran online lebih efektif karena dalam menjalankan bisnis online kelompok Koperasi Cipacing Mandiri dapat membidik target pasar dengan menyesuaikan kebutuhan barang yang sedang hangat saat itu.

Kegiatan PPM ini berjudul Pengembangan kapasitas kelompok Koperasi Cipacing Mandiri melalui Pemasaran Online dalam Menghadapi Pasar Global (ACFTA) yang ditujukan bagi para pelaku UMKM sebagai anggota kelompok Koperasi Cipacing Mandiri di Desa Cipacing. Adapun tujuan dari kegiatan PPM adalah meningkatkan kemampuan para pelaku UMKM di kelompok Koperasi Cipacing Mandiri untuk mengembangkan organisasi dengan menyusun kegiatan dan target pemasaran serta memasarkan hasil produksi 


\begin{tabular}{|c|c|c|c|c|}
\hline $\begin{array}{c}\text { Prosiding Penelitian \& } \\
\begin{array}{c}\text { Pengabdian Kepada } \\
\text { Masyarakat }\end{array}\end{array}$ & $\begin{array}{c}\text { e ISSN : 2581-1126 } \\
\text { p ISSN : 2442-448X }\end{array}$ & Vol 7, No: 1 & Hal: $173-178$ & April 2020 \\
\hline
\end{tabular}

kelompok Koperasi Cipacing Mandiri ke pasar global (ACFTA) dengan memanfaatkan teknologi.

\section{TI NJ AUAN PUSTAKA}

Pengrajin Desa Ciapcing termasuk kedalam kategori pelaku usaha mikro, kecil dan menengah. Untuk memahami kondisi eksisting pengrajin Cipacing perlu didukung oleh kajian teori mengenai pelaku usaha mikro, kecil dan menengah. Banyak pandangan yang membahas tentang usaha mikro, kecil, dan menengah (UMKM). Salah satunya adalah Tambunan (2012:11) yang menyebutkan UMKM sebagai unit usaha produktif yang berdiri sendiri yang dilakukan oleh orang perorangan atau badan usaha di semua sektor ekonomi. Pandangan ini menekankan pada unit usaha mandiri yang dimiliki persorangan atau badan usaha pada sektor-sektor ekonomi. Pandangan lain juga menyebutkan bahwa unit usaha tersebut dicirikan memiliki struktur organisasi yang sederhana dengan jumlah tenaga kerja yang sedikit. Hal tersebut seperti yang dikemukakan oleh Partomo dan Soejono (2002), bahwa secara umum usaha kecil dan menengah memiliki struktur organisasi yang sangat sederhana, jumlah tenaga kerja tidak berlebihan, pembagian kerja yang tidak ketat, sistem managemen yang sederhana, umumnya aktifitas bersifat informal dan jarang menggunakan perencanaan, kurang membedakan aset pribadi dan aset perusahaan.

Selain dari definisi yang dikemukakan di atas, pemahaman mengenai usaha kecil juga dapat dilihat dari Undang-Undang Nomor 20 Tahun 2008 tentang Usaha Mikro, Kecil dan Menengah (UMKM). Disebutkan dalam undang-undang tersebut bahwa ada beberapa kriteria yang dipergunakan untuk mendefinisikan pengertian dan kriteria Usaha Mikro, Kecil dan Menengah menurut jenisnya. Berikut pengertian Usaha Mikro, Kecil dan Menengah berdasarkan jenisnya:

1) Usaha Mikro

Kriteria kelompok usaha mikro adalah usaha produktif milik orang perorangan dan/atau badan usaha perorangan yang memenuhi kriteria usaha mikro sebagaimana diatur dalam Undang-Undang ini. Usaha Mikro merupakan usaha yang memiliki pendapatan maksimal 50 juta rupiah, serta mempunyai aset maksimal 300 juta rupiah.

2) Usaha Kecil

Kriteria Usaha Kecil adalah usaha ekonomi produktif yang berdiri sendiri, yang dilakukan oleh orang perorangan atau badan usaha yang bukan merupakan anak perusahaan atau bukan cabang perusahaan yang dimiliki, dikuasai, atau menjadi bagian baik langsung maupun tidak langsung dari usaha menengah atau usaha besar yang memenuhi kriteria Usaha Kecil sebagaimana dimaksud dalam Undang-Undang ini. Usaha Kecil merupakan usaha yang memiliki pendapatan antara 50 juta-500 juta rupiah, serta mempunyai aset antara 300 juta-2,5 miliar rupiah.

\section{3) Usaha Menengah}

Kriteria Usaha Menengah adalah usaha ekonomi produktif yang berdiri sendiri, yang dilakukan oleh orang perseorangan atau badan usaha yang bukan merupakan anak perusahaan atau cabang perusahaan yang dimiliki, dikuasai, atau menjadi bagian baik langsung maupun tidak langsung dengan usaha kecil atau usaha besar dengan jumlah kekayaan bersih atau hasil penjualan tahunan sebagaimana diatur dalam Undang-Undang ini. Usaha Menengah merupakan usaha yang memiliki pendapatan antara 500 juta-10 miliar rupiah, serta mempunyai aset antara 2,5 miliar-50 miliar rupiah.

Selain dari undang-undang tersebut, klasifikasi usaha mikro, kecil, dan menengah juga dapat dilihat dari klasifikasi yang ditetapkan oleh Bank Indonesia. Klasifikasi tersebut antara lain:

"UMKM adalah perusahaan atau industri dengan karakteristik berupa: (a) modalnya kurang dari Rp. 20 juta (b) untuk satu putaran dari usahanya hanya membutuhkan dana Rp 5 juta (c) memiliki aset maksimum Rp 600 juta di luar tanah dan bangunan, dan (d) pendapatan tahunan $\leq$ Rp 1 miliar. Departemen Keuangan : UMKM adalah perusahaan yang memiliki omset maksimal Rp 600 juta per tahun dan atau aset maksimum Rp 600 juta di luar tanah dan bangunan".

Selain definisi dan klasifikasi, untuk memahami mengenai usaha mikro, kecil, dan menengah juga dapat dilihat dari permasalahan umum yang sering dihadapi pelaku UMKM. Adapun permasalahan tersebut tentunya berbeda-beda satu daerah dengan daerah yang lainnya. Namun demikian, terdapat permasalahan yang umum untuk semua UMKM seperti misalnya modal kerja maupun investasi.

Salah satu pandangan yang menyebutkan permasalahan yang umum dihadapi oleh usaha 


\begin{tabular}{|c|c|c|c|c|}
\hline $\begin{array}{c}\text { Prosiding Penelitian \& } \\
\begin{array}{c}\text { Pengabdian Kepada } \\
\text { Masyarakat }\end{array}\end{array}$ & $\begin{array}{c}\text { e ISSN : 2581-1126 } \\
\text { p ISSN : 2442-448X }\end{array}$ & Vol 7, No: 1 & Hal: $173-178$ & April 2020 \\
\hline
\end{tabular}

kecil dikemukakan oleh Clapham (1991 : 98). Masalah umum yang dihadapi tersebut antara lain:

1) Pengelolaan yang masih sederhana karena berbasis rumah tangga;

2) Sumber daya manusia yang terlibat dalam Usaha Mikro, Kecil dan Menengah ini masih rendah;

3) Tidak adanya pengelolaan keuangan yang jelas;

4) Jumlah produksi dan jenis produksi yang dihasilkan masih sedikit;

5) Pemasaran hasil produksi yang terbatas; dan

6) Kurangnya permodalan.

Lebih lanjut, disebutkan bahwa permasalahan tersebut disebabkan oleh dua faktor yang sangat dominan, yaitu faktor internal kegiatan usaha dan faktor eksternal kegiatan usahanya. Faktor internal lebih terkait dengan sistem usaha tersebut, yang meliputi pengelolaan keuangan, keadaan teknik produksi dan faktor pemasaran. Sedangkan faktor eksternal adalah kebijakan pemerintah dan juga keadaan ekonomi yang berlangsung.

Penelitian lain juga menyebutkan permasalahan umum yang dihadapi oleh UMKM, seperti misalnya hasil survey BPS pada tahun 2003 dan 2005 (dalam Tambunan, 2012 : 53) yang menyimpulkan bahwa permasalahan utama yang dialami pelaku usaha mikro dan usaha kecil adalah keterbatasan permodalan, dan kesulitan pemasaran. Dalam hal pemasaran UMKM umumnya tidak memiliki sumber-sumber daya untuk mencari, mengembangkan atau memperluas pasar-pasar mereka sendiri. Sebaliknya mereka sangat tergantung pada mitra dagang mereka, seperti: pedagang keliling, pengepul atau trading house untuk memasarkan produk-produk mereka atau tergantung pada konsumen yang datang langsung ke tempat produksi mereka.

\section{METODE}

Metode yang digunakan dalam program kegiatan PPM adalah dengan melakukan kegiatan pelatihan yang terdiri dari pemberian materi, diskusi, dan praktik. Kegiatan dipandu oleh narasumber atau tenaga ahli sebagai fasilitator pelatihan dan dibantu dengan seperangkat alat untuk melakukan simulasi secara langsung.

\section{PEMBAHASAN}

Desa Cipacing memiliki pontesi sumber daya manusia yang memiliki keahlian dalam pengelohan kayu yang menghasilkan kerajinan khas. Hasil kerajinan tersebut bervariasi sesuai dengan keahlian masing-masing masyarakat seperti senapan angin, alat musik, layang-layang serta khiasan dari olahan kayu. Oleh sebab itu Desa Cipacing dikenal sebagai penghasil kerajinan tangan yang sudah tersebar keseluruh Indonesia.

Kerajinan merupakan matapencaharian pokok dari sebagian besar masyarakat Desa Cipacing. Beradasarkan data sekunder, diketahui 1.415 orang berprofesi sebagai pengrajin di Desa Cipacing. Untuk mewadahi banyaknya pengrajin di Desa Cipacing maka dibentuklah kelompok Koperasi Cipacing Mandiri di Desa Cipacing. Kelompok Koperasi Cipacing Mandiri kini mewadahi 200 anggota pengrajin dan 150 orang pedagang. Tujuan dibentuknya koperasi ini untuk mensejahterakana anggota dan memajukan industri kerajinan di Desa Cipacing.

Persaingan di pasar lokal sebelumnya terjadi karena pasar dikuasi oleh tengkulak besar yang jumlahnya kurang lebih adalah 20. Persaingan tersebut merugikan pengrajin karena dari hasil penjualan barang kerajinan lebih banyak menguntungkan tengkulak dibanding dengan pengrajin. Kondisi saat ini dipersulit dengan berlaku kebijakan pemerintah terkait Pasar global (ACFTA). Perkembangan industri kerajinan di Desa Cipacing mengalami hambatan setelah berlakunya kebijakan pemerintah terkait Pasar global (ACFTA). Pasar yang dulunya dikuasi pelaku UMKM di Desa Cipacing perlahan mendapatkan saingan barang impor dari luar Indonesia yang membanjiri pasar lokal. Persaingan tersebut tidak berjalan seimbang karena keterbatasan dari kelompok Koperasi Cipacing Mandiri dalam mengekspor barang keluar negara dan kurangnya pengetahuan dalam pemanfaatan teknologi dalam pemasaran global.

Pasar lokal yang dulunya dikuasi pelaku UMKM Desa Cipacing perlahan mendapatkan saingan barang impor dari luar Indonesia yang membanjiri pasar lokal. Persaingan tersebut tidak berjalan seimbang karena keterbatasan dari Pelaku UMKM dalam ekspor barang keluar negara dan kurangnya pengetahuan dalam pemanfaatan teknologi dalam pemasaran global. Dengan memperthatikan kondisi tersebut, maka tim PPM berkesimpulan bahwa perlu adanya kegiatan Pelatihan dan Pengembangan kapasitas Pemasaran Online UMKM di Desa Cipacing dalam Menghadapi Pasar Global (ACFTA) yang ditujukan bagi para pelaku UMKM di Desa Cipacing. Adapun tujuan dari kegiatan PPM adalah meningkatkan kemampuan para pelaku UMKM di kelompok Koperasi Cipacing Mandiri untuk mengembangkan organisasi dengan menyusun kegiatan dan target pemasaran serta 


\begin{tabular}{|c|c|c|c|c|}
\hline $\begin{array}{c}\text { Prosiding Penelitian \& } \\
\begin{array}{c}\text { Pengabdian Kepada } \\
\text { Masyarakat }\end{array}\end{array}$ & $\begin{array}{c}\text { e ISSN : 2581-1126 } \\
\text { p ISSN : 2442-448X }\end{array}$ & Vol 7, No: 1 & Hal: $173-178$ & April 2020 \\
\hline
\end{tabular}

memasarkan hasil produksi kelompok Koperasi Cipacing Mandiri ke pasar global (ACFTA) dengan memanfaatkan teknologi.

Berdasarkan kesimpulan akan pentingnya pengembangan kapasitas pengrajin Desa Cipaicng maka PPM ini melakukan pelatihan. Pelatihan menguraikan materi meliputi alur ekspor barang ke luar Indonesia dan pelatihan pemanfaatan teknologi online untuk pemasaran global serta setelahnya terdapat kegiatan pendampingan untuk ikut berpartisipasi menyusun jadwal kegiatan lembaga serta menentukan target pemasaran. Dalam Pelatihan ini menggunakan metode pendidikan orang dewasa dengan prinsip belajar dai pengalaman. Prinsip inilah yang menjadi landasan pendekatan seluruh proses pelatihan dimana peserta menjadi pelaku utama dalam pencapaian tujuan.

Peserta berpartisipasi aktif dalam kegiatan dengan menjalani setiap tahapan dengan baik dan antusias ditinjau dari banyaknya peserta yang terlibat dalam kegiatan praktik dan tanya jawab. Materi yang diberikan dalam kegiatan ini sesuai dengn Term of Refference (TOR) kegiatan yang diajukn kepada pemateri. Sebelumnya, penyusunan TOR sendiri disesuaikan dengan hasil assesstment yang dilakukan untuk mengetahui materi yang dibutuhkan Pelaku UMKM di Kelompok Koperasi Cipacing Mandiri. Respon yang diberikan oleh peserta cukup bagus, terlihatd ari aktifnya peserta dalam tanya jawab dengan pemateri.

Berdasarkan hasil pre-test dan post test, maka dapat ditinjau bahwa peserta mengalami perubahan yang positif dengan meningkatkan pengetahuan akan ekspor hasil produksi dengan pemanfaatan teknologi untuk pemasaran online. Pengetahuan dan keterampilan peserta semakin meningkat.

Merujuk pada hasil-hasil kegiatan PPM yang telah dilakukan, terutama kegiatan Pengembangan kapasitas kelompok koperasi Cipacing Mandiri melalui pemasaran online dalam menghadapi pasar global melalui pemanfaatan teknologi online maka diperlukan kegiatan pendampingan bagi keberlanjutan pemasaran online. Pendampingan dilakukan guna meningkatkan kreativitas Kelompok Koperasi Cipacing Mandiri dalam mengelola teknologi online hingga mampu menjangkau pasar global. Kegiatan ini dapat dijalankan dengan kegiatan penguatan koperasi
Cipacing Mandiri guna terjalin kerjasama yang berkelanjutan.

\section{Kesimpulan}

Berdasarkan pemetaan dan assestment yang dilakukan mengenai kondisi masyarakat dan potensi sumberdaya yang ada dalam hal ini potensi ekonomi dapat ditelaah dari keadaan mayrotias penduduk Desa Cipacing yang mata pencaharianya didominasi sebagai pengrajin. Sebelumnya, Kelompok Koperasi Cipacing Mandiri mengalami kendala dari berlakunya kebijakan pasar global (ACFTA) karena tidak mampu bersaing akibat kekurangan akses informasi mengenai ekspor barang serta lemahnya pemanfaatan teknologi sebagai strategi pemasaran online. Desa Cipacing merupakan desa penghasil kerajinan nomer satu di Kabupaten Sumedang, laju perkembangan ekonomi di Desa ini merupakan aspek penting dalam pemertanaan kesejahteraan di wilayah. Oleh sebab itu penting bagi stakeholder untuk memperhatikan permasalahan perkembangan industri kerajinan di Desa Cipacing. Dengan memperhatikan kondisi tersebut, maka tim PPM berkesimpulan bahwa perlu adanya sebuah kegiatan yang mampu membrikan dampak positif terhadap peningkatn pemasaran hasil kerajinan dengan mengadakan sebuah kegiatan Pengembangan Kapasitas Kelompok Koperasi Cipacing Mandiri Melalui Pemasaran Online dalam Menghadapi pasar Global (ACFTA).

Pemberdayan dan penguatan kelembagaann pelaku UMKM merupakan proses perubahan pola pikir dengan mempersiapkan sumberdaya manusia menjadi profesional baik dalam teknis pembuatan hasil kerajinan, pemasaran dan pengelolaan organisasi. Dalam kegiatan ini ada 3 faktor yang menjadi indikator bahwa kegiatan memiliki dampak terhadap sasaran pelatihan yaitu keterampilan, pengetahuan dan motivasi. Ketiga faktor ini dikuasi oleh Koperasi Cipacing Mandiri melalui proses tahapan pemberdayaan yang menggunakan sistem, strategi dan metode yang sesuai dengan spesifik total. Untuk itu upaya pendampingan diharapkan menjadi salah stu langkah keberlanjutan program. Pendampingan dilakukan guna meningkatkan kreativitas pelaku UMKM dalam mengelola hasil kerajinan yang memiliki daya jual dan nilai ekonomi yang cukup tinggi. kegiatan ini dijalankan dengan kegiatan penguatan kelompok usaha Koperasi Cipacing Mandiri guna 


\begin{tabular}{|c|c|c|c|c|}
\hline $\begin{array}{c}\text { Prosiding Penelitian \& } \\
\begin{array}{c}\text { Pengabdian Kepada } \\
\text { Masyarakat }\end{array}\end{array}$ & $\begin{array}{c}\text { e ISSN : 2581-1126 } \\
\text { p ISSN : 2442-448X }\end{array}$ & Vol 7, No: 1 & Hal: $173-178$ & April 2020 \\
\hline
\end{tabular}

terjalinnya kerjeasama kelembagaan dengan masyarakat setempat

\section{DAFTAR PUSTAKA}

Clapham, Ronald. 1991. Pengusaha Kecil dan Menengah di Asia Tenggara. Terj. Masri Maris. Jakarta : LP3ES.

Sitompul, Anwar. 2010. Strategi dan LangkahLangkah UMKM dan Koperasi dalam Menghadapi ACFTA. Infokop Vol 18, Juli 2010. Hal $40-51$

Tambunan, Tulus. T. H., 2012. Pasar Bebas ASEAN : Peluang, Tantangan dan Ancaman Bagi UMKM Indonesia. Jakarta : Kementerian Koperasi dan UMKM.

Yusida, Ermita. 2013. Dampak Penerapan ACFTA Terhadap Keberlangsungan Industri Kecil Menengah dilihat dari Perspektif Varian Produk IKM di Jawa Timur. FEB Universitas Brawijaya.

http://www.ilo.org/wcmsp5/groups/public/--asia/---ro-bangkok/---ilojakarta/documents/projectdocumentatio n/wcms_159626.pdf

Undang-Undang Republik Indoneisa Nomor 20 Tahun 2008 tentang Usaha Mikro, Kecil dan Menengah (UMKM). 